\title{
Between Acceleration and Occupation: Palestine and the Struggle for Global Justice
}

\author{
JOHN COLLINS \\ Department of Global Studies, St. Lawrence University
}

\begin{abstract}
This article explores the contemporary politics of global violence through an examination of the particular challenges and possibilities facing Palestinians who seek to defend their communities against an ongoing settler-colonial project (Zionism) that is approaching a crisis point. As the colonial dynamic in Israel/Palestine returns to its most elemental level-land, trees, homes-it also continues to be a laboratory for new forms of accelerated violence whose global impact is hard to overestimate. In such a context, Palestinians and international solidarity activists find themselves confronting a quintessential 21st-century activist dilemma: how to craft a strategy of what Paul Virilio calls "popular defense" at a time when everyone seems to be implicated in the machinery of global violence? I argue that while this dilemma represents a formidable challenge for Palestinians, it also helps explain why the Palestinian struggle is increasingly able to build bridges with wider struggles for global justice, ecological sustainability, and indigenous rights.
\end{abstract}

Much like the ubiquitous and misleading phrase "Israeli-Palestinian conflict," the conventional usage of the term "occupation" to describe Israel's post-1967 control of the West Bank and Gaza serves to deflect attention from the settler-colonial structures that continue to shape the contours of social reality at all levels in Israel/Palestine. ${ }^{1}$ The dominant discourse of "occupation” is built on an unstated assumption that it is the presence of soldiers, whether that presence is viewed as oppressive or defensive, that makes the territories "occupied.” In fact, contemporary Palestine is the site of not one, but two occupations, both of which are occluded by this assumption. The first is the settler-colonial occupation of Palestine by the Zionist project, an occupation that predates 1967. The second, which I will call the Palestinian occupation, is the stubborn, everyday habitation of the land by Palestinians, a human occupation that has always represented Zionism's most fundamental obstacle.

The Palestinian occupation, sometimes expressed via the concept of sumud (steadfastness), is an integral part of a much larger story of anticolonial struggle that also includes militant resistance, street-level popular actions, and a range of efforts in the cultural arena. Attempts to divide Palestinian resistance into "violent" and "nonviolent" streams, often for the purposes of condemning the former, have always

Correspondence Address: John Collins, Department of Global Studies, St. Lawrence University, 82 Park Street, Canton, NY, 13617, USA. Tel: 315.229.5661, Email: collins@stlawu.edu 
been somewhat artificial; most Palestinians, after all, view opposition to Zionism as a long and complex process requiring a flexible toolbox of strategies and tactics that must be adjusted periodically in response to changing local and global conditions of possibility. Analyzing these conditions can help bring into sharper relief the particular challenges facing all those, Palestinians and internationals alike, who seek to resist the structural impact of Zionist colonization.

A useful way of framing these issues is found in Paul Virilio's concept of popular defense. "The principle aim of any truly popular [defense]," writes Virilio (1978/1990, p. 54), "is...to oppose the establishment of a social situation based solely on the illegality of armed force, which reduces a population to the status of a movable slave, a commodity." In this view, popular defense is a venerable human tradition connected with the attempt to resist the particular kinds of exploitation that come with the centralization of political authority (e.g., in the form of the State). ${ }^{2}$ It is also an especially useful way to frame settler colonialism's politics of violence. After all, when not seeking to eliminate indigenous people directly through mass killing, settler projects seek to turn them into "movable slaves" by displacing, confining, and disenfranchising them through a diverse array of violent measures.

The conditions within which a popular defense can be mounted, however, have changed significantly. State repression and popular mobilization alike are now enmeshed in circuits of accelerated global violence. These circuits, in turn, are directly connected with the widespread securitization of politics, with governance increasingly taking the form of "real-time security" in relation to a series of immanent "threats" (Galloway \& Thacker, 2007, p. 74). What does this mean for those who seek to wage an anticolonial struggle for social justice in the $21^{\text {st }}$ century? In this article I explore this question through an examination of the challenges and the possibilities facing Palestinians and others who belong to a growing movement of international solidarity with the Palestinian liberation struggle.

\section{Palestine and the Global}

The struggle for justice in Palestine bears a microcosmic and often prophetic relationship to changing global structures of violence and social control. During the turbulent years of the "long 1960s" (Isserman \& Kazin, 2007), for example, exiled Palestinian revolutionaries responded to a reality they did not choose- the radical delocalization set in motion by the creation of the state of Israel-in a way that revealed a great deal about emerging global realities: they chose to "occupy," in effect, the world's increasingly intricate web of transnational communication and transportation arteries. This decision, which effectively represented a move not just around but beyond national sovereignty, has had significant global consequences (Virilio, 1978/1990).

In contrast, today's Palestinian revolutionaries operate in a context where the struggle has literally returned to its roots: land, trees, rocks, and homes. It is no accident that Israeli state violence in recent years has increasingly taken place in and around these basic elements of Palestinian habitation, nor is it accidental that Palestinian popular defense has drawn many international activists to the West Bank and Gaza. The Palestinian occupation is thus closely connected with what Arturo 
Escobar (2004) describes as the impulse toward "the defence of particular, placebased historical conceptions of the world and practices of world-making” (pp. 222223). These contemporary struggles for social justice, he insists, are "place-based, yet transnationalised.” They retain and seek to defend a deep connection with the land, rejecting both neoliberalism's relentless commodification of life forms and the most extreme kinds of rootlessness associated with a networked world-yet they also pursue their aims by tapping into the very networks that globalizing technologies have helped create.

All of this is happening, however, within dramatically changing-and, it appears, shrinking-conditions of possibility. In part this is a function of traditional geopolitics (the politics of spatial and territorial control): the continuation of Zionism's settler project has left Palestinians, much like the primary victims of settler colonialism in North America and Australia, confined to smaller and smaller pockets of land. The possibility of engaging in a viable popular defense in Palestine, however, is also threatened by other realities that belong in the realm of chronopolitics (the politics of temporal control). In particular, Palestine functions as a kind of laboratory for the deeply underexamined and undertheorized vectors of global acceleration that are continuing to shape not only the changing nature of violence, but also the very possibility of democratic politics.

Acceleration is a general process that permeates all levels of social life (Scheuerman, 2004), albeit in ways that manifest themselves quite unevenly across the globe. Most important for our purposes here is the relationship of acceleration to power and violence, a relationship that has at least two distinct faces. First, as Virilio's critical work on "dromology" (the logic of the dromos, or the race) demonstrates, power is linked as much with speed as it is with wealth: the powerful, "dromocratic" ruler is the one whose hand is on the throttle, with the ability to speed things up or slow things down strategically (Virilio \& Lotringer, 2002, p. 65). At the same time, the dromological perspective insists that we go beyond actor-centered conceptions of power in order to recognize how the very acceleration that benefits particular actors (including, occasionally, subaltern actors) also can take on a life of its own, bypassing anyone's control and rendering everyone vulnerable to new forms of "necropolitics" or "contemporary forms of subjugation of life to the power of death” (Mbembe, 2003).

These two sides of acceleration come together in the form of what I will call dromocratic violence: violence that both uses and is used by acceleration, operating both within and beyond a politics of control. Arguably a form of sovereignty unto itself, acceleration is now integrated into the circuits of "pure war," or the endless preparation for war enabled by the merging of science, technology, communication, and militarization (Virilio \& Lotringer, 1983/1997). No one-not even those who seek to mount a politics of nonviolent resistance-can fully opt out of this system.

Bringing all of these processes together, we can see that the struggle for justice in Palestine finds itself in the difficult position of operating between acceleration (or what might be called the "dromocratic imperative") and occupation (or the "habitational imperative"). There is no question that Israel is heavily invested in the structures and practices of dromocratic power, from its diverse arsenal of mechanisms of social control deployed against Palestinians to its vanguard role in the global "homeland security" economy (Klein, 2007). Some Palestinian groups, in turn, have sought to meet Israel on the dromological level by launching their own 
forms of accelerated violence. The entire colonial dynamic, in this case, continues to provide oxygen to the dromocratic war machine in ways that have damaging global implications (Collins, 2008).

Given this reality, activists working for justice in Palestine are faced with one of the most important political dilemmas of our time: how to maximize one's investment in the politics of occupation while minimizing one's contribution to the politics of violent acceleration. More than an abstract philosophical question of violence vs. nonviolence, it is a question of how to negotiate, in a way that is creative and liberating, the unavoidable issue of one's relationship to and implication in the emerging structures of global violence. At the same time, as I argue in the concluding section, it is precisely this dilemma that creates an increasingly strong basis from which to build bridges with wider movements that are confronting the same dilemma, including movements for global justice, ecological sustainability, and indigenous rights.

\section{Dangerous Walking}

In his remarkable book Palestinian Walks, Ramallah lawyer and human rights activist Raja Shehadeh (2007) narrates a series of lengthy walks through the hills and valleys that make up the "vanishing landscape" of the West Bank, using each as an opportunity to explore the complex ecosystems of the area and the dramatic transformations set in motion by Israeli colonization. One of these walks takes place in 1999, after the creation of the Palestinian Authority (PA) but before the outbreak of the second intifada. In a sort of colonial subcontracting operation during this socalled "Interim Phase," Palestinian security forces were "given” nominal control over small pieces of the West Bank, resulting in an even more byzantine set of checkpoints (both Israeli and PA) and jurisdictions throughout an increasingly fragmented and militarized territory that remained under effective Israeli domination.

As Shehadeh and his wife are trekking through the A'yn Qenya valley, they suddenly come under sustained gunfire. Are the shots coming from Israeli soldiers, Jewish settlers, PA police, or other Palestinian gunmen? Are they being mistaken for settlers or suspected terrorists? After twenty harrowing minutes, they are able to extricate themselves and return home. Later Shehadeh discusses the issue with the Muhafiz (the Palestinian governor of Ramallah), who suggests that the shooters had been a group of shabab (young Palestinian men) engaging in target practice and says matter-of-factly, "You shouldn't go to the valley.” For Shehadeh, a lifelong hiker and defender of Palestinian land rights, hearing this message from a fellow Palestinian is too much to bear:

“They mustn’t do this,” I said. “There are shepherds there and others who walk in the hills. I have been walking for twenty-five years. Nothing ever happened to me in these hills. I never had to worry. People should be encouraged to walk in the hills. It will increase their attachment to their country.” The Muhafiz didn't agree. "You shouldn’t walk," he repeated in a concerned paternal tone. "It's much too dangerous." (Shehadeh, 2007, p. 92) 
The settler-colonial dynamic in Palestine has reached a Kafkaesque point where authorities invested in the structures of dromocratic violence are inclined to blame civilians who remain invested in the most basic activities. As Anthony Hall (2003) argues, this sort of attitude is integral to the expansionist logic of settler colonialism and its "transient frontierism" (p. 24). Notwithstanding powerful patriotic discourses that invoke the beauty of the land and the need to defend it, settler projects tend to be oriented toward the violent conquest of territory rather than the peaceful occupation of it. Drawing on the work of Wendell Berry, Hall writes that this orientation has produced in North America "a pattern of sustained hostility towards any group that wove its way of life together with its sense of identity into the ecological fabric of a particular place” (p. 24). The same argument applies to the settler-colonial hostility toward the indigenous population of Palestine. ${ }^{3}$

Shehadeh's surreal experience appears prophetic in light of "Operation Cast Lead,” Israel's 2008 assault on Gaza. Describing the attitude of the Israeli military toward Palestinian civilians during the attack, one Israeli soldier demonstrated precisely what happens when the logic of the Muhafiz ("You shouldn't walk. It's much too dangerous") is merged with the realities of dromocratic violence. "If we detect any thing that should not be there-we shoot," the soldier observed. "We're told the air force distributed flyers telling everyone to go to Gaza City. If beyond this line any people are detected-they are not supposed to be there" (PCATI, 2009, p. 18).

The soldier's testimony, while laudable for its honesty, is ultimately redundant. After all, within the terms of the settler-colonial project, Palestinians by definition are "not supposed to be there," and the policies of the settler state are geared toward the perpetual demonstration of that definition. As the authors of the PCATI report point out, the confined and carceral realities of Gaza (a territory of only 139 square miles) meant that the Israeli policy of pushing civilians to flee their homes guaranteed that large numbers of civilians would find themselves on the street and therefore considered, in the words of one Israeli commander, "not innocent" and "doomed to die" (p. 19).

\section{Israel's “War on the Milieu”}

What happened in Gaza is not simply the product of a specific and relatively recent dynamic between Israeli and Hamas violence; it is also the culmination of Israel's entire post-1967 policy vis-à-vis the Palestinians, a policy that serves continued colonization and illustrates the operational logic of permanent war. Even as it was projecting its military reach externally toward the exiled Palestinian guerrillas, the Israeli state was establishing a strategy of perpetual counterinsurgency in the West Bank and Gaza, a strategy that has increasingly taken the form of what Virilio (1976/1998, p. 30) calls "war on the milieu." He distinguishes this from an earlier model ("war of milieu") in which war was waged within a specific arena (e.g. the "Pacific theatre"). In the newer model, war is waged directly on civilians, their capacity for biological and social reproduction, and the natural and built environment that ensures their survival.

In Virilio's subtle change of preposition from "war of milieu" to "war on the milieu,” we find an important clue to understanding Israel’s policy in the West Bank 
and Gaza. As the late Edward Said was fond of pointing out, the Zionist/Israeli colonization of Palestine has always been a policy of extraordinary detail symbolized by Chaim Weizmann's mantra, “another acre, another goat” (Said, 1994). This policy, in other words, has its own (colonial) ecology rooted in the careful and systematic attempt to manage the natural and built environment to its own advantage, if necessary by destroying it.

Nothing illustrates the logic of Israel's war on the milieu more clearly than the systematic destruction of olive trees and its devastating impact on Palestine's economy. In a sustained campaign that recalls a host of U.S. actions directed against the milieu in many places from the western plains of North America to the jungles of Vietnam and the cities of Iraq, the Israeli military has uprooted hundreds of thousands of olive trees since 1967 . This process has accelerated significantly during the construction of the Wall in recent years, lending credence to the notion that the Wall constitutes a broad colonial system unto itself. ${ }^{4}$

An equally visible aspect of Israel's war on the milieu has been its practice of eliminating Palestinian homes, whether through direct demolition, systematic discrimination against non-Jews in the issuing of building permits, or the "collateral damage" associated with military campaigns. ${ }^{5}$ The military's use of overwhelming force in urban environments has extended this aspect of the colonial project to a wider range of structures including mosques, hospitals, factories, and government buildings. This development is reflected in the difference between 2002's "Operation Defensive Shield” in the West Bank (approximately 900 buildings destroyed) and “Operation Cast Lead" (nearly 4,000 buildings destroyed in space roughly onefifteenth the size of the West Bank) only six years later (PCATI, 2009, p. 24).

Nor has this ecological war stopped at the ground level. A less visible aspect of the colonial project is the diverting of water resources from underneath the feet of Palestinians. Yet while the water issue has received a fair amount of attention from scholars, journalists, and political negotiators, another underground issue-the politics of sewage-has remained largely ignored. Eyal Weizman (2007) connects the sewage issue with Zionism's "hygienic phobia" that "sees the presence of Palestinians as a 'defiled' substance within the 'Israeli' landscape” (p. 20). ${ }^{6}$ Once again, the most extreme manifestation of the issue is to be found in Gaza, where periodic sewage crises garner momentary attention as much for their "threat" to Israel as for what they say about the living conditions of Palestinian refugees.

The politics of sewage points us to an understanding of the biopolitical nature of the war on the milieu. Gaza, in particular, has been the site of what amounts to a sustained experiment in emerging forms of social control (Li, 2006). Cut off from the outside world by the Israeli policy of "closure," Gazans have found themselves targeted by the weaponization of food. In a move that connects directly with a global trend toward militarized humanitarianism, Israel's control of access to Gaza proceeds through a combination of collective punishment and the occasional provision of food to prevent mass starvation. The opening paragraph of a 2006 New York Times report illustrates this process perfectly, noting that Israeli authorities had briefly opened the main crossing into Gaza "to allow delivery of flour and sugar to Palestinians," only to close it thirty minutes later "citing security threats" (Myre, 2006). By reducing many Palestinians to "bare life" (Agamben, 1998), this policy bears primary responsibility for a well-documented pattern of food insecurity, stunted growth, 
deteriorating public health conditions, and psychological trauma in Gaza (Giacaman et al., 2009; Roy, 2009).

Finally, and equally biopolitical, one of the most devastating effects of the creation of Israel's web of checkpoints during the post-Oslo years has been to place the very process of reproduction at special risk as women on their way to the hospital are forced to wait, sometimes for hours, at checkpoints. Meanwhile, perhaps owing to its ongoing national obsession with maintaining Jewish demographic superiority, Israel is also a world leader in assisted reproductive technologies, thus making it a pioneer in global colonization's newest incarnation: the colonization of the body by technology (Virilio \& Lotringer, 2002, p. 101). ${ }^{7}$ When placed in the broader context of the processes discussed in this section, Israel's politics of reproduction echo the settler-colonial biopolitics of North America (Smith, 2005) in forming an important part of its war on the milieu.

\section{Habitational Resistance}

The cumulative material effects of Israel's war on the milieu have dramatically altered the political horizon of Palestinian nationalism and the conditions within which Palestinians engage in the popular defense of their communities. There is little doubt, for example, that the phenomenon of Palestinian suicide bombing is at least partly a product of this changing political environment (Hage, 2003). More generally, however, the war on the milieu has left the majority of ordinary Palestinians on the ground with little option but to embrace the kind of existential resistance has always constituted the most implacable obstacle to the settler-colonial project and its "logic of elimination." 8

Shehadeh's book is emblematic of a tradition of Palestinian occupation that has long formed the bedrock of the popular struggle against this project. This Palestinian occupation has been present throughout the period of settler colonization but has been relatively ignored thanks to Zionism's ideological success in focusing the attention of external observers on more spectacular forms of Palestinian resistance. Recent developments have given the Palestinian occupation greater visibility as the politics of survival and habitation take center stage. With its emphasis on an unhurried and grounded relationship with place, the Palestinian occupation is also opposed to the dromocratic structures in which the state of Israel and some of its adversaries-those who seek faster and more effective ways of visiting violence upon Israelis-are heavily invested.

Equally important, Shehadeh's story of being shot at by Palestinian gunmenyoung men linked with the extensive security apparatus created after Oslo as part of what was ostensibly a kind of proto-state structure-illustrates a tension between sovereignty and what might be called self-sovereignty, a tension that cannot be resolved satisfactorily by appealing to state-centered anticolonial nationalism. ${ }^{9}$ As the dream of a truly independent Palestinian state fades into oblivion, more and more Palestinians find themselves engaging in different forms of habitational resistance. The things they are defending are less the things that make for sovereignty and more the things that make for self-sovereignty.

One of the by-products of this gradual shift is that it makes the settler-colonial nature of the situation more visible to all. Within Israel and in the diaspora, Zionism is 
reaching a crisis point that is reducing the ideological space available to those who might wish to separate Zionism from its settler foundations. Among Palestinians, articulations of an "indigenous" identity-that is, a "Fourth World" identity that would suggest strong linkages with, say, the Cherokee (Finkelstein, 1995) or aboriginal Australians (Wolfe, 2006) - have historically been rare when compared with the salience of pan-Arab, pan-Islamic, or pan-“Third World” solidarity. Yet the necessary shift toward a politics of habitation has left Palestinians with a growing need to prioritize one of the cardinal, near-ontological principles of indigenous identity and power in a settler-colonial world: the refusal to leave the land and disappear. Existence, in this sense, is resistance.

The case of Abdel Fattah Abed Rabbo illustrates the lengths to which a settlercolonial project will go in order to oppose this existential resistance. In November 2009 the 48-year-old Abed Rabbo found himself facing eviction from a cave he was occupying in the hills between Jerusalem and Bethlehem. It appears that he was targeted for eviction more than once, most recently because of plans to build a new colony, Givat Yael, as part of Israel's ongoing expansion of Jerusalem on land annexed illegally in 1980. An earlier report spotlighting Abed Rabbo's plight notes the irony of charging a cave-dweller with lacking a building permit. "Don't charge me," countered Abed Rabbo. "Charge nature” (Ross, 2009). Settler colonialism, of course, does both: it "charges" not only the colonized but also their "natural" connection to the land, a connection that frustrates the settler project and provokes the very "ecological struggle" (Virilio, 1978/1990) the settler state must then violently suppress.

The experience of violent and continuing dislocation generates in refugees not only a deep longing for return, but also new attachments to the very places to which they have been dislocated and confined. Communities such as Balata refugee camp, for example, have a palpable sense of collective identity and determination to engage in popular defense (Collins, 2004), even against the most aggressive forms of Israeli military assault (Weizman, 2007, pp. 185-221). Similarly, Palestinian refugees in Gaza have developed a strong sense of Gazan identity despite having been pushed to live there against their will. In short, the Palestinian occupation to which I am referring is a product not only of centuries of habitation in Shehadeh's West Bank hills, but also of the deterritorialization wrought by settler colonialism.

This Palestinian occupation has always had as its basic building block the actions of families on the micro level. With colonization largely taking the daily, inexorable form of "another acre, another goat," Palestine is full of examples of families and individuals, like Abed Rabbo, who have spent literally years struggling against land confiscation within the Israeli court system and staying on their land amidst the colonial encroachment. Here one is reminded of Virilio's (1978/1990) description of the family as the foundational source of social solidarity and, even more provocatively, the original "commando group" (pp. 80-82). States and the military class that often control them typically seek to disrupt this network by cultivating suspicion within families and communities, as Israel has done through its system of collaborators throughout the West Bank and Gaza since 1967.

The politics of habitational resistance historically have found further expression in the long tradition of Palestinian collective action at the community level, such as the growth of popular committees (lijân shacbiyye) during the first intifada. These 
committees addressed a wide range of tasks related to popular defense, from medical relief and clandestine education to local security and food production (Lockman \& Beinin, 1989; Nassar \& Heacock, 1991). Such efforts, however, built upon a process of popular organizing that had been building steadily throughout the two decades after 1967 (Hasso, 2005; Taraki, 1991). Women, youth, students, workers, shopkeepers, farmers-all of these groups have been centrally involved in resistance to Israeli rule.

It would be an exaggeration to say that ecological awareness has played a major role in the Palestinian liberation movement to date. With the growth of an indigenous consciousness, however, comes the recognition, to quote former American Indian Movement spokesman John Trudell (2008), that "we are the land” (p. 224). In such a context, the simple act of walking in the hills becomes more than a recreational pastime, even more than a way of claiming political sovereignty; it becomes an act of habitational resistance. As the war on the milieu raises the ecological stakes, it also produces new ways of conceiving the project of anticolonial resistance. ${ }^{10}$

\section{“Gravity and Density”}

The increased visibility of habitational resistance in Palestine is partly due to the presence of the international solidarity activists who provide direct support to the nonviolent struggles of ordinary Palestinians. Now more than ever, the popular defense of Palestine is a globalized process. The growth in collaboration between Palestinian communities and activists affiliated with the International Solidarity Movement (ISM) and other groups during the past decade (Dudouet, 2006; Kaufman-Lacusta, 2010; Seitz, 2003) has coincided with the escalating process of dromocratic confinement described above.

When Edward Said wrote presciently in 1993 of the "principle of confinement" animating the practices of U.S. imperialism, he also identified an "elusive oppositional mood....an internationalist counter-articulation," effectively prefiguring the rise of the ISM and, more broadly, the new global justice movement (p. 311). Many of the movements associated with this global "counter-articulation" have consciously responded to the "principle of confinement" by insisting on their right to inhabit streets, abandoned buildings, and other public spaces. Taking back the notion of occupation, in other words, is an important component of the activist networks that make up a global movement for which attachment to the Palestinian cause is an increasingly prominent element.

In the case of some, of course, it is a shallow and highly romanticized attachment that does not stretch beyond the exercise of political fashion statements such as wearing a kufiya. In other cases, however, the connection with Palestine is more deeply felt and becomes the basis for life-changing decisions. In one of his last and most powerful articles, Said addressed the story of American activist Rachel Corrie, crushed to death by an Israeli bulldozer in 2003 while defending a Palestinian home in Gaza, and used it as an occasion to reflect on the continuing and growing power of the solidarity movement:

What Rachel Corrie's work in Gaza recognized was precisely the gravity and the density of the living history of the Palestinian people as a national 
community, and not merely as a collection of deprived refugees. That is what she was in solidarity with. And we need to remember that that kind of solidarity is no longer confined to a small number of intrepid souls here and there, but is recognized the world over. (Said, 2004, p. xv)

In invoking the ideas of "gravity" and "density," Said called attention to the transformation that often occurs when activists cross the geographic threshold and find themselves on the ground in Palestine, feeling the weight not only of the deep structures put in place by settler colonization, but also of the tenacious occupation maintained by the colonized.

The key practices of the solidarity movement are those associated with the nonviolent politics of habitational resistance: witnessing, documenting, standing with Palestinians in their homes and at checkpoints, assisting with the harvesting of olives under the threat of settler violence, and, perhaps most visibly, working in communities that are most directly affected by the construction of the Wall. Communities such as Qalqilya and Bil'in (http://www.bilin-village.org/english/), sharply victimized by land confiscations, have become internationally-known focal points of Palestinian popular defense. These sites are laboratories not only of Israeli colonization, but also of grassroots action, including the practice of activists chaining themselves to trees.

\section{Reviving Popular Defense}

When the Nobel Committee announced its decision to award its 2004 Peace Prize to Wangari Maathai, the Kenyan environmental activist best known for planting trees, more than a few observers raised their eyebrows. In her acceptance speech, Maathai acknowledged that the committee had done something unusual by choosing to recognize her work in founding the Green Belt Movement and championing the causes of reforestation and (literal) grassroots empowerment. "The committee, I believe, is seeking to encourage community efforts to restore the earth," she said, "at a time when we face the ecological crises of deforestation, desertification, water scarcity and a lack of biological diversity" (Maathai, 2004).

The world's only superpower had other ideas. The day before Maathai accepted her Nobel Prize, the U.S. Congress passed legislation authorizing the Federal Aviation Administration to issue permits for space tourism at a time when American officials were talking hopefully about the future colonization of Mars. Settler colonizers, it seems, are willing to pay almost any price in order to escape the grassroots. For much of the rest of the world, however, the importance of protecting trees is self-evidently a matter of life and death. The choice of Maathai represented a recognition of the organic relationship between the struggle for peace and the struggle to defend the biosphere, including and especially the most vulnerable communities that inhabit it, against the impact of a predatory system of global colonization that combines endless capital accumulation with war on the milieu. The growing awareness of global climate change and the related global food crisis have only heightened the need for creative strategies.

It is here that Virilio's suggestive discussion of "popular defense" comes most directly into play. The heyday of popular defense, he argues, was an earlier period 
when local communities were more easily able to defend themselves and their land, whether through sabotage or through other strategies of slowing down the dromocratic invader. The replacement of the ancient "right to armed defense" with the kind of "military protection racket" that formed the basis of modern states, however, began a steady process of reducing the possibility of a successful popular defense (Virilio, 1978/1990, pp. 45-46). The exponential shift in violence set in motion by modern military inventions from the machine gun to the ballistic missile, he suggests, dramatically accelerated this process.

In many ways, the age of high globalization has seen the gap between popular defense and the power of the war machine widen even further. Moreover, the shift from geopolitics to chronopolitics means that the very notion of place itself is under siege as "time displaces space as the more significant strategic 'field"' for dromocratic elites (Der Derian, 1990, p. 308). Are there any places left to defend, or are we only inhabiting time now? Reading Virilio's work, one almost gets the impression that the game is over, leaving us with no choice but to play out the apocalyptic string from within a dromocratic prison. Within this pessimistic framework, contemporary movements for popular defense are no more than quixotic remnants of a vanished past.

Or perhaps not. As the example of today's Palestinians and their international solidarity comrades suggests, the urge to defend locality through various forms of popular defense remains a powerful impulse with a growing sense of global urgency. The limitation of Virilio's perspective in this case derives from having been seduced by the particular realities of globalization and globalized violence that were emerging in the 1970s. By reading the Palestinian situation solely through the lens of its most deterritorialized and deterritorializing elements-namely, the nomadic hijackers who turned popular defense into a suicidal "popular assault" and the Israeli state's borderless military response to this development-he rendered invisible the continuing ecological and habitational presence of Palestinians on the land.

\section{Activism and Dromocratic Violence}

The power of popular defense, in Palestine or anywhere else, is not to be underestimated. Neither, however, should it be romanticized or exaggerated. The great value of the dromological approach is that when combined with close attention to what is happening on the ground, it helps us understand the dilemma with which I began this article. While drawing their motivation and their moral strength from the imperatives of occupation, individuals and communities seeking to engage in popular defense also inevitably find themselves confronted by the realities of acceleration. The same technologies that enable them to communicate, educate the public, and bear witness to what is happening on the ground also enable others to carry out dromocratic violence with increasing speed and lethality. The activist's dilemma, then, is how to negotiate a path between acceleration and occupation without being swallowed by the former.

The Gaza tunnel system that has been targeted in recent years by the Israeli military is an interesting example of this dilemma. Created as a response to the carceral conditions that prevailed after the Israeli "disengagement” from the territory, the tunnels undoubtedly serve an ecological function: they enable Palestinians in 
Gaza to keep inhabiting the land without completely running out of food or fuel. They also constitute a powerful symbolic device that can be mobilized and circulated globally as evidence of Palestinian suffering and desperation. At the same time, their military function of facilitating the entry of weapons tells us that the tunnels also serve to push forward the very dynamic of violent acceleration that is shaping life for Gaza's population. Many Palestinians, for understandable reasons, might see this as a necessary contradiction, perhaps because they have been forced again into a position where they feel they have no choice but to launch a "popular assault.” But it remains a contradiction, one that reveals a great deal about the starkly limited situation that colonization has produced in Palestine.

The implication to be drawn from Virilio's provocative framework is that engaging in a true popular defense today requires eschewing, to the greatest extent possible, the politics of violent acceleration. In a world of immanent securitization, however, no one can claim to be fully outside the circuits of violence; even a philosophical commitment to pacifism doesn't guarantee that one can control the effects of one's own actions. These global realities, combined with the highly complex and dangerous political environment in Palestine, mean that activists working for popular defense there must continually negotiate their own relationship to local agents of dromocratic violence.

While it is not impossible to imagine isolated individuals affiliated with the solidarity movement who might deliberately engage in clandestine cooperation with armed Palestinian groups, or even with the Israeli state, the larger issue is that the global structures of dromocratic violence leave all activists vulnerable to unintended consequences. The pro-Israeli propaganda campaign against global solidarity activists in Palestine leverages precisely this fact by taking a movement that presents itself as nonviolent and attempting to reframe it as a material supporter of the kind of terrorism (in the form of suicide bombings) that must be subject, in the dominant public discourse, to “absolute moral condemnation” (Hage, 2003, p. 67). The networked nature of contemporary violence and the representation of violence means that solidarity activists can never refute such charges definitively.

\section{Between the Third World and the Fourth}

The dilemmas facing solidarity activists point us toward one of the most important social justice questions of the $21^{\text {st }}$ century: how to politicize acceleration. In the same way that workers' movements helped politicize wealth, or feminism and other "new social movements" helped politicize identity, what is needed now is a kind of global occupation movement that opposes militarization through a habitational politics in order to make visible the relationship between acceleration and the permanent social war that we see all around us. Fortunately, we also see all around us evidence of what amounts to the social basis for such a movement.

The broad, coalitional orientation of the World Social Forum is one of the key elements of this picture, but it has also found itself subject to a variety of critiques. Created primarily as a grassroots response to the claim that "there is no alternative" to the globalization of neoliberal capitalism, the WSF has been criticized for privileging the perspectives and the leadership role of middle-class, educated 
populations and also for being significantly whiter than the larger population it claims to represent (Teivainen, 2002). The opposition of these relatively privileged groups to the dominant system, some suggest, is drastically undercut by their often unacknowledged investment in it, an investment symbolized by their level of comfort in inhabiting the placeless world of the internet at a time when more marginalized populations are engaged in place-based struggles.

Similarly, the Forum's origins in the critique of capitalism initially had the effect of downplaying some of the issues (e.g., environmental sustainability, militarization) and perspectives (e.g., those of indigenous people) that would presumably be most central to maintaining and strengthening the tradition of popular defense. More recently, however, there are indications that the WSF and the many national and regional forums it has spawned are moving toward a more inclusive approach in response to both internal critiques and the emerging realities of "imperial globality" and "global coloniality" in which "the global economy comes to be supported by a global organisation of violence and vice versa" (Escobar, p. 214). Boaventura de Sousa Santos, one of the most prominent intellectuals associated with the WSF, signalled this direction shortly after the launch of the U.S. war on Iraq in 2003, arguing for a "strategic shift" that would recognize the struggle against militarization as "a necessary condition for the success of all the other struggles" (Santos, 2003). The integration of issues related to environmental sustainability represents a further step along this path toward a political framework that would underpin an integrated response to the global war on the milieu.

The shift that Santos envisions is not a minor one, nor is it necessarily a palatable one for those who insist that war is simply a tool of capital. Nonetheless, refusing to subordinate the struggle against militarization to a narrow anti-capitalist politics is arguably more in tune with the global realities that colonization in general, and settler colonialism in particular, have fostered in the modern era. For this reason, it is also more in tune with the "tradition of the oppressed" (Benjamin, 1978, p. 257) that arguably finds its clearest expression in the perspectives of those who have been targeted, displaced, and enslaved by settler-colonial projects.

In this light, it is hardly accidental that the idea of "globalization from below" has coincided with a renewed global politics of indigeneity. The WSF itself probably could not have emerged without the impetus provided by the 1994 Zapatista uprising, which articulated its identity and its goals explicitly in response to a 500year system combining violent colonization and, more recently, neoliberal capitalist exploitation. With the Zapatistas in mind, Hall (2003) argues that the alternative traditions of sovereignty associated with indigenous people, in fact, represent the "last line of defence" against unchecked corporate globalization (p. 150).

There are indications that the WSF's "movement of movements" has begun to redress the marginalization of indigenous voices, a development that could have farreaching consequences (Conway, 2009). Such a shift can only help the process of exploring the linkages among militarization, neoliberalism, and global climate change at a time when new thinking is sorely needed. Indigenous people, of course, are not the only people who have good reason to mount a determined politics of occupation and popular defense; the same holds true for all those who are facing structural violence and dislocation. Without question, however, indigenous voices are of central importance in pushing for a renewed ecological politics focused on core issues of land, water, food, and climate-issues that are also of concern to many 
within the global privileged class, including those who populate the various "slow movements" that often prioritize sustainability and a return to small-scale agriculture (particularly organic agriculture).

The political convergences we are seeing on the level of Escobar's "place-based yet transnationalised" social movements suggest a step away from the kind of "Third Worldist" approach rooted firmly in modernity. In reaching toward something that is "beyond" modernity, they have much in common with the kind of "Fourth World" thinking that has always been suspicious of the linear, hierarchical thinking imposed by colonial projects and internalized by many anti-colonial nationalists (Hall, 2003). At the same time, as Escobar rightly notes, "many of the conditions that gave rise to Third Worldism have by no means disappeared" (p. 207).

This gray area between Third and Fourth World realities and responses is precisely where the Palestinian struggle is currently located. For those who see it as the last remaining struggle against colonialism, it is the quintessential Third World issue awaiting resolution in the form of Palestinian statehood. For others, however, Palestine's primary importance lies in its connection with wider struggles for social, economic, and even environmental justice. ${ }^{11}$ This may explain why Palestine continues to be one of the most unifying issues within the lively, diverse, and often contentious global justice movement. While moments of confrontation with supporters of Israel remain unavoidable, the primary debates within the movement have concerned strategic questions such as the relative value of government sanctions on Israel vs. the civil society-based approach that has produced growing calls for divestment and boycotts in recent years ("Palestinian Strategic Options").

With Palestine's status as cause célèbre for global justice activists, of course, come a number of dangers. Not least of these, as noted above, is the danger of romanticization (Bhattacharyya, 2008). Perhaps even more concerning, however, is the danger of oppressive orthodoxy. To the extent that an undifferentiated notion of "Palestine" becomes an article of faith within the global justice movement, it becomes more difficult for anyone to ask critical questions about the relationship between Palestinian resistance, international solidarity, and the deeper structures within which both are embedded.

What these dangers highlight is the importance of making sure that solidarity does not, as Said famously warned, have the effect of blinding its adherents and silencing the kind of critical reflection that is the lifeblood of any struggle for social justice. ${ }^{12}$ Regardless of the exact path that the global justice movement takes, there is little doubt that solidarity will provide the glue holding together these efforts and enabling them to connect productively with the global movement for justice in Palestine. As I have argued here, the search for effective and liberating responses to the structures of dromocratic violence-structures that are organically related to settler colonialism and its ongoing global impact-remains a key point of convergence that gives everyone a stake in the struggle to maintain the Palestinian occupation. 


\section{Notes}

1 For some of the most incisive contributions to a growing literature on Palestine and settler colonialism, see Elkins and Pederson (2005); Piterberg (2008); Shafir (1996); Veracini (2006); and Wolfe (2006).

2 Virilio's essentially anarchist perspective views the State as a "permanent conspiracy" engaged primarily in the business of domination and resource extraction. He distinguishes domination from the sort of "pure power" that stretches beyond the control of politics and manifests itself, for example, in processes of runaway militarization.

3 The architects of Zionism, as Joseph Massad (2005) and others have argued, saw themselves as emissaries of "progress" and "civilization" who would, as the popular slogan goes, "make the desert bloom." This formulation reveals a great deal about how Palestine's indigenous population has been positioned within settler discourse. The same formulation also provides a context for understanding a range of contemporary Israeli discourses that praise Israel's high-tech economy, cutting-edge farming techniques, and other features while marking Palestinians as the antithesis of this ultra-modernity and/or obstacles to its full realization.

4 For an extended discussion of how the construction of the Wall has affected Palestinian farmers, see Makdisi (2008).

5 The Israeli Committee Against House Demolitions (www.icahd.org) is an excellent resource for information on this issue. ICAHD places the number of Palestinian homes demolished since 1967 at over 24,000 .

6 Weizman also notes that thanks to the chaotic building and destruction that have taken place in the "wild frontier of the West Bank," raw sewage has proven to be quite uncontrollable, often ending up in Israel despite the intentions of Israeli authorities to keep it contained in Palestinian areas.

7 For a detailed discussion of Israeli "nationalist biopolitics," including the aggressive provision of contraceptives and abortion services for Palestinians who live in Israel, see Kanaaneh (2002).

8 Patrick Wolfe (2006) uses the term "logic of elimination" to designate one of the basic characteristics of settler-colonial projects of the sort undertaken in Australia, North America, South Africa, and Palestine: the desire to create a new society in place of an existing one. While such projects do not always result in genocide, Wolfe argues persuasively that they do seek the "elimination" of the indigenous population through some combination of forced removal, mass killing, and biocultural assimilation.

9 I owe this distinction to Ghassan Hage, and in particular to his plenary lecture at the 2008 "New Worlds, New Sovereignties" conference held in Melbourne. If sovereignty typically refers to the desire to establish and maintain formal control over territory and other people, self-sovereignty refers to the desire to feel "at home" in the world and to feel some sense of control over one's own circumstances. In Hage's reading, colonial sovereignty is inherently linked with ecological domination and the desire to "domesticate" the Other by denying and/or killing the Other's political will.

10 The Bustan Qaraaqa (Tortoise Garden) project located in the West Bank town of Beit Sahour, for example, is a deliberate experiment in the kind of "permaculture" that seeks to create "sustainable human habitats by following nature's patterns, using the stability and resilience of natural ecosystems to provide a framework and guidance for people to develop their own sustainable solutions to the problems facing their world” (Bustan Qaraaqa).

${ }^{11}$ The marketing of Palestinian olive oil as part of the global "solidarity economy" in recent years is a good example of how international activists who are well-connected on the ground in Palestine have been able to build bridges with wider ecological struggles. The same olive tree that has nationalist significance for Palestinians and political significance for activists who lend their hands to the annual olive harvest campaign in the West also has ecological significance for consumers who may not necessarily be personally involved in the Palestinian liberation struggle.

12 In his classic essay on "Secular Criticism," Edward Said (1983) argues that "solidarity before criticism means the end of criticism” (p. 28). Though this formulation might itself be critiqued for privileging the position of the cosmopolitan intellectual, it nonetheless cautions wisely against the dangers of a solidarity that closes itself off from the fresh air of critical dialogue. 


\section{John Collins}

\section{References}

Agamben, G. (1998). Homo sacer: Sovereign power and bare life (D. Heller-Roazen, Trans.). Stanford, CA: Stanford University Press.

Benjamin, W. (1978). Illuminations: Essays and reflections (H. Arendt, Ed., H. Zohn, Trans.). New York, NY: Schocken Books.

Bhattacharyya, G. (2008). Globalizing racism and myths of the other in the "war on terror.” In R. Lentin (Ed.), Thinking Palestine (pp. 46-61). London: Zed.

Bustan Qaraaqa. (n.d.). Why permaculture?

Retrieved from http://www.bustanqaraaqa.org/al2/web/page/display/id/8.html.

Collins, J. (2004). Occupied by memory: The Intifada generation and the Palestinian state of emergency. New York, NY: NYU Press.

Collins, J. (2008). Confinement under an open sky: Following the speed trap from Guernica to Gaza. Globalizations, 5(4), 555-569.

Conway, J. (2009, March 13). Indigenizing the global at the World Social Forum. Alternatives International. Retrieved from http://www.alterinter.org/article3069.html.

Der Derian, J. (1990). The (s)pace of international relations: Simulation, surveillance and speed. International Studies Quarterly, 34, 295-310.

Dudouet, V. (2006). Cross-border non-violent advocacy during the second Palestinian intifada: the case of the International Solidarity Movement. Paper presented at Coventry University seminar on "Unarmed Resistance-the Transnational Factor.”

Retrieved from http://www.civilresistance.info/files/V\%C3\%A9ronique\%20Dudouet_0.pdf.

Elkins, C., \& Pederson, S. (Eds.). (2005). Settler colonialism in the twentieth century: Projects, practices, legacies. New York, NY: Routledge.

Escobar, A. (2004). Beyond the third world: Imperial globality, global coloniality and anti-globalisation social movements. Third World Quarterly, 25(1), 207-230.

Finkelstein, N. (1995). History's verdict: The Cherokee case. Journal of Palestine Studies, 24(4), 32-45.

Galloway, A., \& Thacker, E. (2007). The exploit: A theory of networks. Minneapolis, MN: University of Minnesota Press.

Giacaman, R. et al. (2009). Health status and health services in the occupied Palestinian territory. The Lancet, 373(9666), 837-849.

Hage, G. (2003). “Comes a time we are all enthusiasm”: Understanding Palestinian suicide bombers in times of exighophobia. Public Culture, 15(1), 65-89.

Hall, A. J. (2003). The American empire and the fourth world. Montreal \& Kingston: McGill-Queen's University Press.

Hasso, F. (2005). Resistance, repression and gender politics in occupied Palestine and Jordan. Syracuse, NY: Syracuse University Press.

Isserman, M., \& Kazin, M. (2007). America divided: The civil war of the 1960s, 3rd ed. New York, NY: Oxford University Press.

Kanaaneh, R.A. (2002). Birthing the nation: Strategies of Palestinian women in Israel. Berkeley, CA: University of California Press.

Kaufman-Lacusta, M. (2010). Refusing to be enemies: Palestinian and Israeli nonviolent resistance to the Israeli occupation. Reading, NY: Ithaca Press.

Klein, N. (2007, June 16). How war was turned into a brand. Guardian. Retrieved from http://www.guardian.co.uk/commentisfree/2007/jun/16/israel.comment1.

Li, D. (2006). The Gaza Strip as laboratory: Notes in the wake of disengagement. Journal of Palestine Studies 35(2), 38-55.

Lockman, Z., \& Beinin, J. (Eds.). (1989). Intifada: The Palestinian uprising against Israeli occupation. Boston, MA: South End Press.

Maathai, W. (2004). Nobel lecture. Retrieved from http://nobelprize.org/nobel_prizes/peace/laureates/2004/maathai-lecture-text.html.

Makdisi, S. (2008). Palestine inside out: An everyday occupation. New York, NY: W.W. Norton.

Massad, J. (2005). The persistence of the Palestinian Question. Cultural Critique, 59, 1-23.

Mbembe, A. (2003). Necropolitics. Public Culture, 15(1), 11-40.

Myre, G. (2006, March 21). Israel briefly reopens a Gaza crossing to send in food. New York Times. Retrieved from http://www.nytimes.com. 
Nassar, J. R., \& Heacock, R. (Eds.). (1991). Intifada: Palestine at the crossroads. New York, NY: Birzeit University and Praeger Publishers.

Palestinian cave-dweller fights Israeli eviction. (2009, November 12). Haaretz. Retrieved from http://www.haaretz.com/hasen/spages/1127461.html.

Palestinian strategic options: An attempt at analysis to inform action. (2005). Journal of Palestine Studies 35(1), 91-102.

Piterberg, G. (2008). The returns of Zionism: Myth, politics, and scholarship in Israel. London: Verso.

Public Committee Against Torture in Israel. (2009). No second thoughts: The changes in the Israeli Defence Forces' combat doctrine in light of "Operation Cast Lead." Jerusalem: PCATI. Retrieved from http://www.stoptorture.org.il/files/no\%20second\%20thoughts_ENG_WEB.pdf.

Ross, O. (2009, April 12). The caveman's day in court. The Star. Retrieved from http://www.thestar.com/comment/columnists/article/617187

Roy, S. (2009). If Gaza falls.... London Review of Books, 31(1), 26. Retrieved from http://www.lrb.co.uk/v31/n01/sara-roy/if-gaza-falls-

Said, E. (1983). The world, the text and the critic. Cambridge, MA: Harvard University Press.

Said, E. (1993). Culture and imperialism. New York, NY: Alfred A. Knopf.

Said, E. (1994). The acre and the goat. In E. Said, The politics of dispossession: The struggle for Palestinian self-determination, 1969-1994 (pp. 33-42). New York, NY: Pantheon.

Said, E. (2004). Foreword: the meaning of Rachel Corrie. In Sandercock, J. et al. (Eds.), Peace under fire: Israel/Palestine and the International Solidarity Movement (pp. xiii-xxii). London: Verso.

Sandercock, J., Sainath, R., McLaughlin, M., Khalili, H., Blincoe, N., Arraf, H., \& Andoni, G. (Eds). (2004). Peace under fire: Israel/Palestine and the International Solidarity Movement. London: Verso.

Santos, B. (2003). Collective suicide? Bad Subjects, 63. Retrieved from http://bad.eserver.org/issues/2003/63/santos.html.

Scheuerman, W. E. (2004). Liberal democracy and the social acceleration of time. Baltimore and London: The Johns Hopkins University Press.

Seitz, C. (2003). ISM at the crossroads: The evolution of the international solidarity movement. Journal of Palestine Studies, 32(4), 50-67.

Shafir, G. (1996). Land, labor, and the origins of the Israeli-Palestinian conflict, 1882-1914. Berkeley, CA: University of California Press.

Shehadeh, R. (2007). Palestinian walks: forays into a vanishing landscape. New York, NY: Scribner.

Smith, A. (2005). Conquest: sexual violence and Native American genocide. Boston, MA: South End Press.

Taraki, L. (1991). The development of political consciousness among Palestinians in the Occupied Territories, 1967-1987. In J. R. Nassar \& R. Heacock (Eds.), Intifada: Palestine at the crossroads (pp. 53-71). New York, NY: Birzeit University and Praeger Publishers.

Teivainen, T. (2002). The World Social Forum and global democratisation: Learning from Porto Alegre. Third World Quarterly, 23(4), 621-632.

Trudell, J. (2008). Lines from a mined mind. Golden, CO: Fulcrum.

Veracini, L. (2006). Israel and settler society. London: Pluto Press.

Virilio, P. (1990). Popular defence \& ecological struggles (M. Polizzotti, Trans.). New York, NY: Semiotext(e). (Original work published in 1978)

Virilio, P. (1998). The suicidal state. In J. Der Derian, (Ed.), The Virilio Reader (pp. 29-45). Malden, MA: Blackwell. (Original work published in 1976)

Virilio, P., \& Lotringer, S. (1997). Pure war (M. Polizzotti, Trans.). New York, NY: Semiotext(e). (Original work published in 1983)

Virilio P., \& Lotringer, S. (2002). Crepuscular dawn (M. Taormina, Trans.). Los Angeles \& New York: Semiotext(e).

Weizman, E. (2007). Hollow land: Israel's architecture of occupation. London: Verso.

Wolfe, P. (2006). Settler colonialism and the elimination of the native. Journal of Genocide Research, 8, 387-409. 